\title{
Time delay and associated mortality from negative smear to positive Xpert MTB/RIF test among TB/HIV patients: a retrospective study
}

Miguelhete Lisboa ${ }^{1,2^{*}}$ (D) Inês Fronteira ${ }^{2}$, Estefano Colove ${ }^{1}$, Marques Nhamonga ${ }^{1}$ and Maria do Rosário O. Martins ${ }^{2}$

\begin{abstract}
Background: The GeneXpert MTB/RIF Assay $\left(\right.$ Xpert $\left.^{\oplus}\right)$ is known to be a feasible, effective and a hopeful tool for rapid tuberculosis (TB) diagnosis and treatment. However, little is known about the time delay caused by initial negative sputum smear microscopy (NSSM), but consecutive positive Xpert TB test (PXTBt) and its association with TB mortality in resource-constrained settings. We aimed to estimate the median time delay between initial NSSM but consecutive PXTBt and TB treatment initiation and its association with TB mortality among TB/HIV co-infected patients in Beira, Mozambique.
\end{abstract}

Methods: we used data from a retrospective cohort study of TB/HIV co-infected patients in six TB services in Beira city. The study included all patients that tested NSSM, followed by a PXTBt in the six health centers with TB services during the year 2015. Data were extracted from the laboratory and TB treatment registers. To assess the difference in median time delays between groups, Mann-Whitney and Kruskal-Wallis tests were computed. To analyze the associations between the time delays and TB mortality, logistic regression model was used.

Results: Among the 283 patients included in the study, median (IQR) age was 31 (17) years, 59.0\% were males, 57.6\% in the WHO clinical fourth stage of HIV. The median (IQR) values for diagnostic delay, treatment delay and total time delay was 10 (9) days, 13 (12) days and 28 (20) days, respectively. For TB/HIV co-infected patients who tested negative for smear microscopy initially, a total time delay of one month or longer was associated with high mortality ( $\mathrm{aOR}=12.40,95 \% \mathrm{Cl}: 5.70-22.10)$.

Conclusion: Our study indicates that delays in TB diagnosis and treatment resulting from initial NSSM, but consecutive PXTBt are common in Beira city and are one of the main factors associated with TB mortality among TB/HIV co-infected patients. Applying GeneXpert assay as gold standard for HIV-positive patients with suspected pulmonary TB or replacing the sputum smear microscopy by Xpert assay and its availability within $24 \mathrm{~h}$ is urgently needed to ensure early diagnosis and treatment, and to maximize the impact of the few resources available in the country.

Keywords: TB/HIV co-infection, Negative smear microscopy, GeneXpert MTB/RIF, Delay TB diagnosis \& treatment, TB mortality, Beira-Mozambique

\footnotetext{
* Correspondence: miguelhetelisboa@gmail.com

${ }^{1}$ Centro de Investigação Operacional da Beira (ClOB), Instituto Nacional de

Saúde (INS), Rua Correia de Brito \#1323 - Ponta-Gea, Beira, Mozambique

${ }^{2}$ Global Health and Tropical Medicine, Instituto de Higiene e Medicina

Tropical (IHMT), Universidade NOVA de Lisboa (UNL), Rua da Junqueira $N^{\circ}$

100 |, 1349-008 Lisbon, Portugal
}

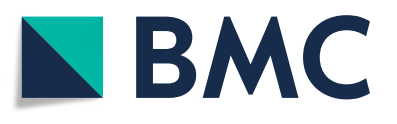

(c) The Author(s). 2019 Open Access This article is distributed under the terms of the Creative Commons Attribution 4.0 International License (http://creativecommons.org/licenses/by/4.0/), which permits unrestricted use, distribution, and reproduction in any medium, provided you give appropriate credit to the original author(s) and the source, provide a link to the Creative Commons license, and indicate if changes were made. The Creative Commons Public Domain Dedication waiver (http://creativecommons.org/publicdomain/zero/1.0/) applies to the data made available in this article, unless otherwise stated. 


\section{Background}

Tuberculosis (TB) diagnosis and treatment delays increase the risk of spreading TB in the community and in health facilities [1-3], developing severe disease and death, particularly in TB/HIV co-infected patients $[1,3,4]$. Additionally, TB remains one of the most common opportunistic infections and the major cause of morbidity and mortality in people living with HIV [5-7]. Of the 10.4 million new TB cases worldwide in 2016, an estimated $10 \%$ where associated with the Human Immunodeficiency Virus (HIV) and $22.3 \%$ of all TB deaths were HIV positive [8].

Mozambique ranks in 14th place among the 30 countries with the highest burden of TB, with incidence rates estimated at 551/100,000 inhabitants in the general population and 284/100,000 inhabitants in the HIV-infected population. The TB/HIV co-infection rate in Mozambique is estimated at $44 \%$, being one of the highest in the world [8].

In 2015, Beira city reported a $\mathrm{TB}$ incidence rate estimated at 659/100,000 inhabitants. Among the 3034 new TB cases in 2015, about $63 \%$ tested positive for HIV demonstrating that both, TB incidence and TB/ HIV co-infection rates in Beira are above the national average [9].

TB/HIV co-infection represents a huge challenge for TB control, particularly in low-income countries, such as Mozambique. One of the main strategies for TB control is to reduce transmission through early detection and rapid administration of proper anti-TB treatment $[10,11]$. However, several studies and systematic reviews of literature have shown that there are both patient delays and health care system delays that hinder TB diagnosis and treatment [12-16].

While the World Health Organization's recommendation [17] from 2014 has incorporated GeneXpert as gold standard for the diagnosis of HIV positive adults with suspected TB, Mozambique's guidelines are still lagging behind. In line with the national guideline for the implementation of GeneXpert MTB/RIF (Xpert) [18] health facilities without GeneXpert should perform acid-fast bacilli smear microscopy as the first method of choice to diagnose TB. Patients with HIV or other immunosuppressive conditions (diabetes, pregnancy, etc.) that are suspected to have TB, are only referred to GeneXpert assay, after receiving negative results for the acid-fast bacilli smear microscopy [18] Fig. 1.

On the other hand, using the signs and symptoms [19], pulmonary X-ray $[20,21]$ and sputum smear microscopy $[22,23]$ for the diagnosis of pulmonary TB in HIV-infected patients has been appointed to be inefficient and considered as important risk factors for delays in TB diagnosis and treatment, particularly among TB/ HIV co-infected patients [24, 25].
However, little is known about the possible time delays in TB treatment initiation that result from initial negative sputum smear microscopy in TB/HIV co-infected persons. As further research is needed to show the extent to which much morbidity and mortality is associated with the time delays in TB diagnosis and treatment initiation among TB/HIV co-infected patients in Beira, our study aimed to estimate the median time delay in TB diagnosis and treatment, as well as TB mortality associated with both types of delays among patients co-infected with TB/HIV.

\section{Methods}

\section{Study design, population and sample}

This was retrospective cohort study conducted in the all six health centers with $\mathrm{TB}$ services in Beira city, from January to December 2015. TB laboratory and treatment registers were retrospectively reviewed. We purposively retrieved only data of all pulmonary TB/HIV co-infected patients who had an initial negative sputum smear microscopy; but were subsequently found to have positive GeneXpert MTB test. Therefore, patients with previous positive GeneXpert MTB test, positive sputum smear microscopy and extra pulmonary $\mathrm{TB}$, were excluded from the study.

In Mozambique, HIV patients start to take HAART when they are at WHO stage 3 or 4 regardless CD4+ count or at WHO stage 1 or 2 with CD4+ count below $500 \mathrm{cel} / \mathrm{mm}^{3}$. However, currently, Mozambique is piloting a new "test and treat" strategy, by which every HIV positive person is offered HAART. Since 2016, combined fixed dose drugs are available and used accordingly. The recommended first and second choices for adults HIV treatment are $\mathrm{TDF}+3 \mathrm{TC}+\mathrm{EFV}$ or $\mathrm{AZT}+3 \mathrm{TC}+\mathrm{NVP}$ or $\mathrm{ABC}+3 \mathrm{TC}+\mathrm{EFV}$ and $\mathrm{AZT}+3 \mathrm{TC}+\mathrm{LPV} / \mathrm{r}$ or $\mathrm{TDF}+$ $3 \mathrm{TC}+\mathrm{LPV} / \mathrm{r}$ or $\mathrm{ABC}+3 \mathrm{TC}+\mathrm{LPV} / \mathrm{r}$, respectively [26]

On the other hand, isoniazid, rifampicin, ethambutol, and pyrazinamide are the combined fixed dose drugs used for the treatment of TB. In addition, injectable drugs such as streptomycin, kanamycin, amikacin, ofloxacin, levofloxacin, ethionamide and cycloserine are available drugs for the 2nd line regimen [27].

\section{Study operational definitions}

Time delays under investigation of this study are:

(a) the delay to diagnosis with GeneXpert assay considered as difference in days between negative smear microscopy and positive GeneXpert assay

(b) the delay to treatment initiation - considered as difference in days between positive GeneXpert assay and proper TB drug administration 


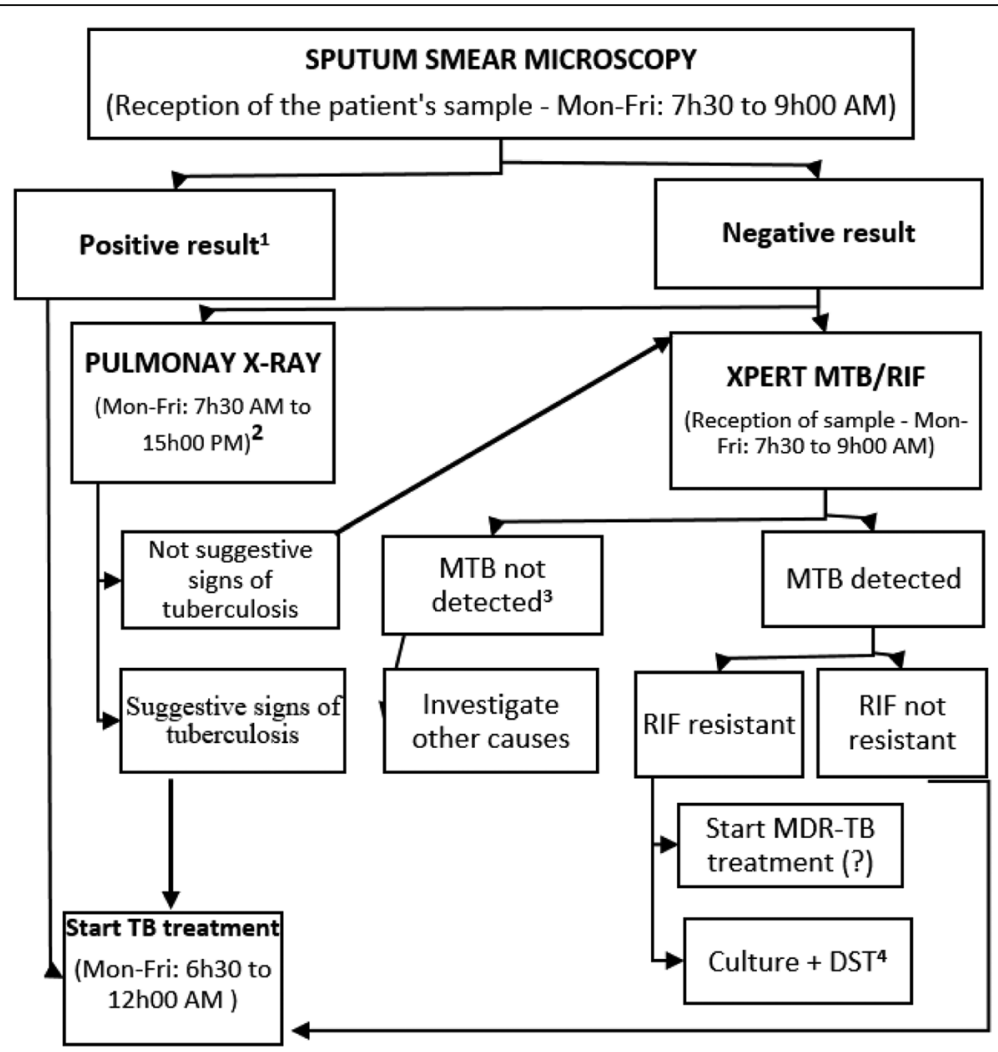

\begin{abstract}
${ }^{1}$ Sputum smear microscopy results are available one day after sample delivery from 11 h00 AM to 15 h00 PM, except if the sample delivery was on Friday or the next day is a local or national holiday. ${ }^{2}$ Except in the Beira central hospital where X-ray is available 24 hours/day, but subject to being scheduled for 1 or 2 days later. ${ }^{3}$ Xpert results in the 5 out 6 TB treatment centres in Beira, are available 2 or 3 weeks after sample delivery. Underutilization of the only one Xpert machine available for TB services in Beira ( 7 hours/dav), subsequent accumulation of samples and, lack of communication and management of the samples and their results, are the main factors associated with Xpert TB test results delays. ${ }^{4}$ Currently, the reference TB lab in Beira is not performing any MTB culture neither DST for 2 years ago. Samples are being sent to the Maputo reference TB lab. Waiting time: up to 8 weeks.
\end{abstract}

Fig. 1 Current flowchart for TB diagnosis in Beira city

(c) the total time delay - considered as difference in days between having a negative smear microscopy and treatment initiation.

\section{Study site and TB services}

The study was carried out in Beira city (the capital of Sofala province) central region of Mozambique. Beira is the 2nd largest city in Mozambique (after Maputo city, capital of Mozambique) located about $1200 \mathrm{~km}$ northern of Maputo, with population estimated about 463,442 inhabitants in 2017, which $50.2 \%$ are male [28].

Beira city has a referral TB laboratory for the central region of the country, installed in the Beira central hospital (HCB). This laboratory has the ability to culture $M$. tuberculosis, drug sensitivity test, in addition to the diagnosis of TB through Gene Xpert MTB/RIF and smear microscopy based on fluorescence. Additionally, in the primary health care network, there are 6 of the 13 primary healthcare facilities that have TB diagnosis and treatment services, namely: Macurungo, Munhava, Mascarenhas, Nhaconjo, Chingussura and Ponta-Gêa health centers.

Among the primary healthcare facilities above-listed, Ponta-Gêa is the only one out of the six primary healthcare facilities with TB services equipped with GeneXpert MTB/RIF technology, X-ray machine, higher number of high qualified lab technicians, nurses, and medical doctors. Additionally, Ponta-Gêa is the largest TB and HIV center in Beira city. The available Xpert machine in Ponta-Gêa health facility is a 4-module configuration, therefore Xpert sample testing response is also delayed due to sample overload and limited working hours of the TB laboratories Fig. 2. 


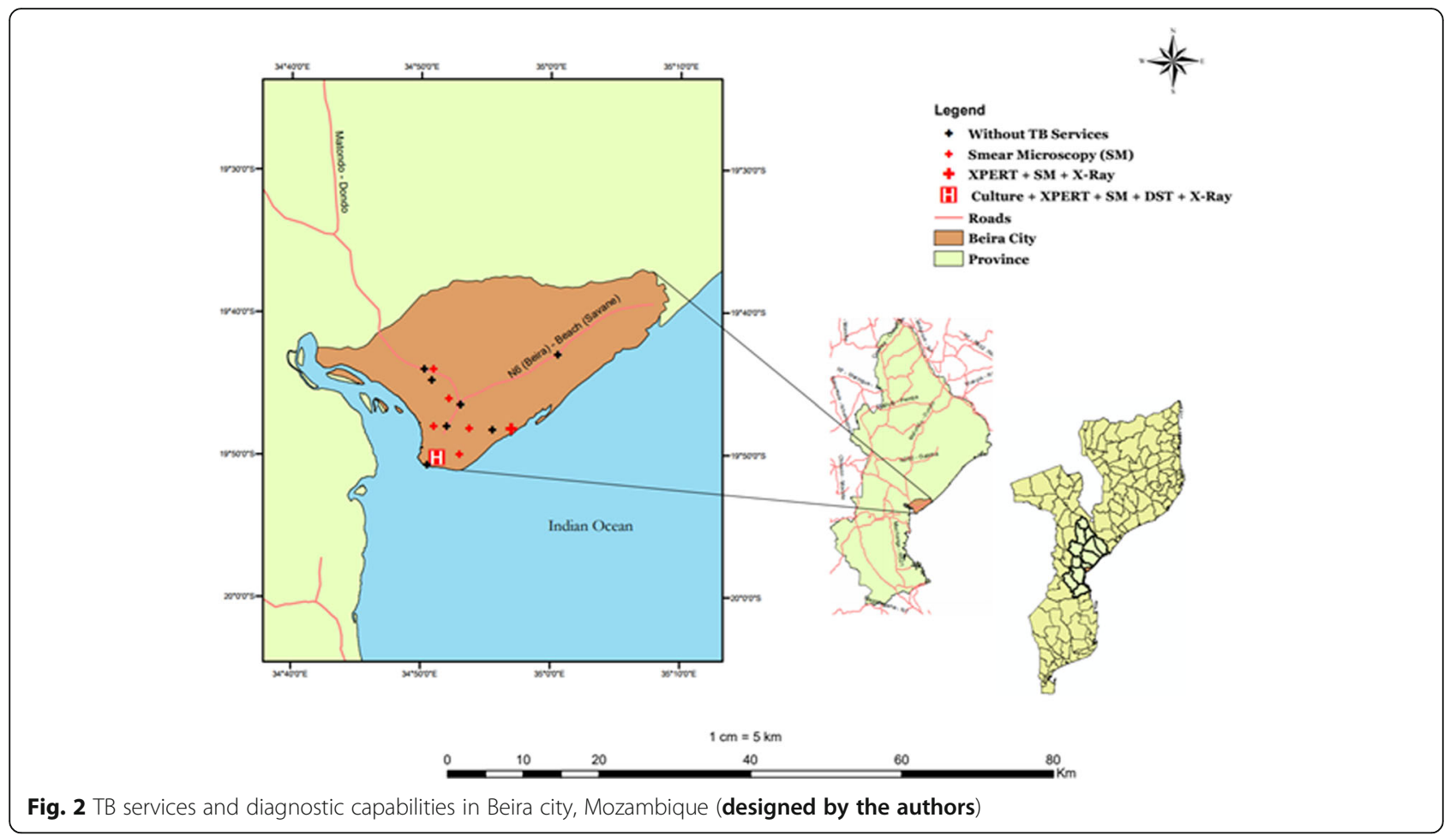

Variables and, inclusion or exclusion criteria

Demographic and clinical data such as sex, age, HIV and treatment status, WHO clinical stages of HIV, sputum smear microscopy result, Gene Xpert sputum results, as well as (a) the date recorded for negative smear microscopy, (b) the date recorded for positive GeneXpert assay, (c) the date recorded for anti-Tuberculosis treatment initiation and (d) the treatment outcome, were retrospectively extracted from the laboratory and treatment registration books.

Patients without data in relation to HIV and TB treatment outcome, and/or transferred out to other health facilities out of the Beira city, were excluded from the analysis.

\section{Data analysis}

The collected data were introduced, cleaned and analyzed using Statistical Package for Social Sciences (SPSS) version 20 for Windows. Descriptive statistics: frequencies, percentages, medians and interquartile range were used to present the data. The time delay from negative sputum smear microscopy initially documented, followed by a positive GeneXpert assay that demonstrated pulmonary Tuberculosis to $\mathrm{TB}$ treatment initiation was assessed.

To assess the difference in different median time delays between groups we used Mann-Whitney and Kruskal-Wallis nonparametric test. To analyze the associations between the several types of time delays and TB mortality among TB/HIV co-infected patients, logistic regression model was used. We computed adjusted odds ratio (aOR) and its respective 95\% confidence interval. We consider a significance level of $5 \%$ for all statistical analysis.

\section{Results}

\section{Patient characteristics}

A total of 428 pulmonary TB/HIV co-infected patients were submitted for Xpert sputum test after negative sputum smear microscopy in Beira city, between January and December 2015. Of these, 283 (66.1\%) had complete information and were included in the data analysis. Missing information was related to incomplete treatment outcomes records of 37 patients, incomplete $\mathrm{TB}$ diagnosis, age and highly active antiretroviral therapy (HAART) information of 12 patients, lost to follow-up of 23 patients, treatment failure of 16 patients and, 58 transferred out, and hence with unknown $\mathrm{TB}$ treatment outcomes Fig. 3.

From the total TB/HIV co-infected patients, 167 (59.0\%) were males and $164(58.0 \%)$ were on HAART. The median (interquartile range - IQR) age was 31 [17] years and the most frequent age category was 25-34 years old (39.2\%). Forty-nine (17.3\%) of the patients had MTB detected and RIF resistant while the remaining 


\section{TOTAL RECRUITED}

429 pulmonary TB/HIV coinfected Patients with negative smear microscopy submitted to Xperet MTB/RIF

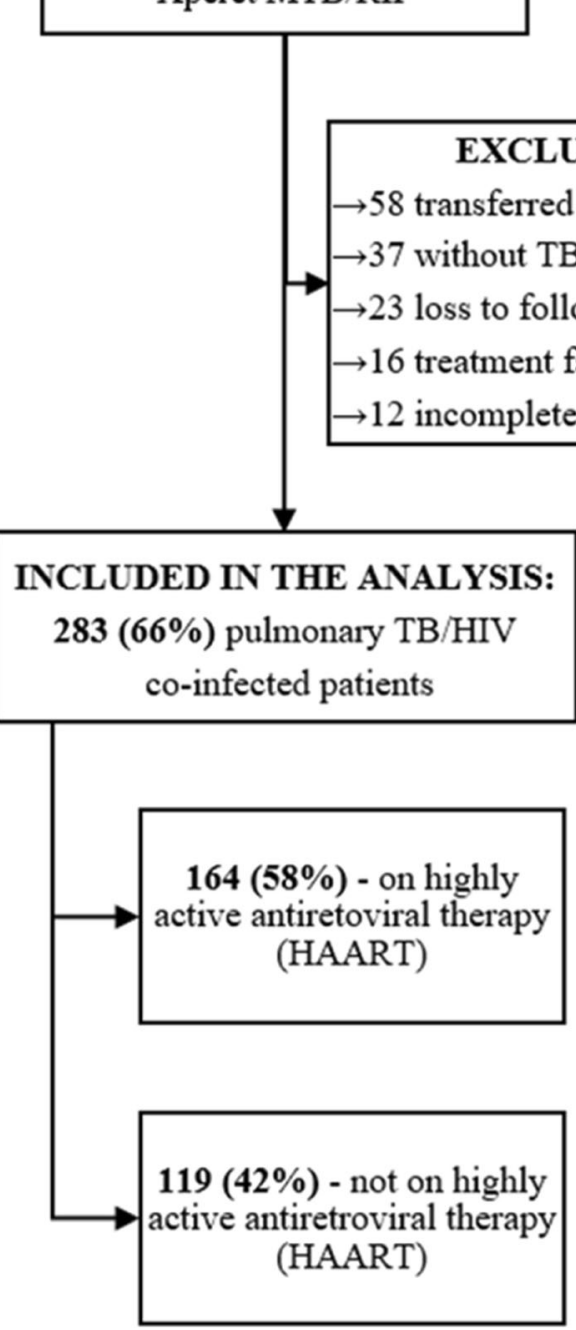

Fig. 3 Schematic representation of study population and selection procedure

were not resistant. The majority, 163 (57.6\%) of the TB/ HIV co-infected patients had more advanced HIV disease (WHO clinical 4th stage of HIV), 158 (55.8\%) died during $\mathrm{TB}$ treatment and the remaining completed the TB treatment successfully (Table 1 ).

\section{Median time delays in TB diagnosis and treatment}

The total median (IQR) time delay was 28 [20] days. The median (IQR) time delay from the initial negative sputum smear microscopy (NSSM) to the positive Xpert TB test (PXTBt) and, from this point to the TB treatment initiation was 10 [9] days and, 13 [12] days, respectively.
The median time delay from the initial negative sputum smear microscopy (NSSM) to TB treatment initiation is not statistically different between the sex and among the age groups $(p>0.05)$. However, statistically significant differences in the median time delays were observed among the TB treatment centers, between those with successful treatment outcome and those who died and, between patients with WHO clinical 3rd and 4th stages of HIV $(p<0.05)$.

Details about median time delays from NSSM to PXTBt and from PXTBt to TB treatment initiation are given (Table 2). 
Table 1 General characteristics of pulmonary TB/HIV co-infected patients with positive Xpert spuum test and registered for treatment in 2015 in Beira city, Mozambique

\begin{tabular}{|c|c|c|}
\hline Characteristics & Number & Percentage (\%) \\
\hline \multicolumn{3}{|l|}{ Sex } \\
\hline Male & 167 & 59.0 \\
\hline Female & 116 & 41.0 \\
\hline \multicolumn{3}{|l|}{ Age groups } \\
\hline $15-24$ years old & 65 & 23.0 \\
\hline 25-34 years old & 111 & 39.2 \\
\hline $35-44$ years old & 50 & 17.7 \\
\hline $45-54$ years old & 28 & 9.9 \\
\hline$>55$ years old & 29 & 10.2 \\
\hline \multicolumn{3}{|c|}{ WHO clinical stages of HIV } \\
\hline Stage 3 & 120 & 42.4 \\
\hline Stage 4 & 163 & 57.6 \\
\hline \multicolumn{3}{|c|}{ M.tuberculosis/rifampicina (MTB/RIF) } \\
\hline Resistant & 49 & 17.3 \\
\hline Not resistant & 234 & 82.7 \\
\hline \multicolumn{3}{|c|}{ Highly active antirretroviral therapy (HAART) } \\
\hline On HAART & 164 & 58.0 \\
\hline Not on HAART & 119 & 42.0 \\
\hline \multicolumn{3}{|l|}{ Treatment outcome } \\
\hline Died & 158 & 55.8 \\
\hline Completed & 125 & 44.2 \\
\hline
\end{tabular}

\section{Tuberculosis mortality and its correlates}

The majority of patients (55.8\%) died during TB treatment. Estimation results indicated that sex and age groups are not statistically associated with mortality $(p>0.05)$, while time delay in TB diagnosis and treatment increases the probability of TB death.

A patient with TB/HIV co-infection who has a time delay of up to 28 days (aOR $=4.02,95 \%$ CI: 2.31-9.92), when compared to the reference class ( $\leq 7$ days of delay), is 4 times more likely to die from tuberculosis, adjusting for other factors; while a patient with a time delay of more than a month $(\mathrm{aOR}=12.40,95 \% \mathrm{CI}: 5.70-22.10)$, is over 12 times more likely to die, adjusting for other factors (Table 3).

The WHO clinical stages of HIV infection, highly active antiretroviral therapy (HAART) status and localization of TB treatment centers are also associated with mortality. Thus, a patient in the WHO clinical 4th stage of HIV (aOR $=5.45,95 \%$ CI: 3.11-9.56) when compared with 3rd stage of HIV is 5 times more likely to die from TB adjusting for other factors. Similarly, patient that is not on HAART (aOR $=6.86,95 \%$ CI: 3.94-11.95), when compared with those on HAART, is 6 times more likely to die from TB adjusting for other factors.
Additionally, patients treated in Ponta-Gea TB center (the reference group) are less likely to die from $\mathrm{TB}$, adjusting for other factors.

\section{Discussion}

One of the main findings of this retrospective study is the median (IQR) time delay of 28 [20] days in the $\mathrm{TB}$ diagnosis and treatment estimated from the initial negative sputum smear microscopy (NSSM) to TB treatment initiation. Similar studies have found a median (IQR) health system delay of 62 (83) days across all health facilities in Beira city among all $\mathrm{TB}$ suspected patients [16].

Despite the political commitment and increased governmental efforts in the last 10 years, the availability of $\mathrm{TB}$ services still strives to meet demands: based on the national labor law [29], the TB labs and TB treatment centers within the public health facilities are open from 7:30 AM to 3:30 PM and 7:30 AM to 12:00 $\mathrm{PM}$, respectively, during working days. TB treatment centres and sputum sample examination are not performed on weekends or holidays.

Additionally, in line with the national guideline for the implementation of GeneXpert MTB/RIF [18], patients with HIV suspected to have TB within health facilities without GeneXpert MTB/RIF machine are only referred to Xpert assay after receiving negative results for the acid-fast bacilli smear microscopy. Unfortunately, as Xpert machine is only available in one out of the six primary healthcare facilities with $\mathrm{TB}$ services and is a 4-module configuration, the Xpert sample testing response is also delayed due to sample overload and limited working hours of the TB laboratories.

However, despite the ongoing contribution for TB control in resource-limited settings, using the signs and symptoms [19], pulmonary X-ray [20, 21] and sputum smear microscopy $[22,23]$ for the diagnosis of pulmonary TB in HIV-infected patients has been reported to be inefficient and an important risk factors for delays in TB diagnosis and treatment [24, 25].

Therefore, as the TB/HIV co-infection rate in Beira city is estimated at 63\% [9] and most of patients present their selves to the health facility at advanced stage of HIV infection, which has been associated with a negative sputum smear microscopy [30,31], the use of the Xpert MTB/RIF within the primary healthcare facilities (currently: one out six) at first attempt to $\mathrm{TB}$ diagnosis among TB/HIV co-infected patients in Beira city should be promoted and available $24 \mathrm{~h}$ per day to ensure early pulmonary TB diagnosis and prompt initiation of proper treatment.

Our data also demonstrate that the mortality rate was $55,8 \%$ among TB/HIV co-infected patients who had negative sputum smear microscopy (NSSM) at first 
Table 2 Median time delays from negative smear microscopy to TB treatment through positive Xpert test among pulmonary TB/HIV co-infected patients during 2015 in Beira city, Mozambique

\begin{tabular}{|c|c|c|c|}
\hline \multirow[t]{3}{*}{ Characteristics } & \multicolumn{3}{|c|}{ Delays in TB diagnosis and Treatment (DAYS) } \\
\hline & From NSSM to PXTBt & From PXTBt to TB Treatment initiation & From NSSM to TB Treatment initiation \\
\hline & Median (IQR) & Median (IQR) & Median (IQR) \\
\hline \multicolumn{4}{|l|}{ Sex } \\
\hline Male & $9(13)$ & $14(14)$ & $30(23)$ \\
\hline Female & $7.5(8)$ & $13(11)$ & $26(19)$ \\
\hline p-value (Mann-Whitney U) & 0.127 & 0.579 & 0.364 \\
\hline \multicolumn{4}{|l|}{ Age groups } \\
\hline $15-24$ years old & $7(7)$ & $13(13)$ & $27(21)$ \\
\hline $25-34$ years old & $9(11)$ & $14(11)$ & $29(17)$ \\
\hline $35-44$ years old & $9(9)$ & $13(15)$ & $27(20)$ \\
\hline $45-54$ years old & $12.5(14)$ & $14(10)$ & $33.5(26)$ \\
\hline$>55$ years old & $11(7)$ & $12(6)$ & $25(15)$ \\
\hline p-value (Kruskal-Wallis) & 0.303 & 0.905 & 0.585 \\
\hline \multicolumn{4}{|l|}{ TB treatment center } \\
\hline Ponta-Gea & $5(12)$ & $8(4)$ & $13(23)$ \\
\hline Macurungo & $13(8)$ & $13(12)$ & $26(10)$ \\
\hline Manga Mascarenha & $11(8)$ & $17(8)$ & $33.5(20)$ \\
\hline Munhava & $11(10)$ & $15(12)$ & $32(12)$ \\
\hline Nhaconjo & $12(13)$ & $14(9)$ & $27(11)$ \\
\hline Chingussura & $13(22)$ & $15.5(9)$ & $36(24)$ \\
\hline p-value (Kruskal-wallis) & 0.001 & 0.001 & 0.001 \\
\hline \multicolumn{4}{|l|}{ TB treatment outcome } \\
\hline Completed & $7(9)$ & $10(11)$ & $23(19)$ \\
\hline Died & $11(10)$ & $14.5(12)$ & $31.5(20)$ \\
\hline p-value (Mann-Whitney U) & 0.013 & 0.001 & 0.001 \\
\hline \multicolumn{4}{|l|}{ WHO clinical satage of HIV } \\
\hline Stage 3 & $9(8)$ & $11(11)$ & $22(15)$ \\
\hline Stage 4 & $7(13)$ & $19(13)$ & $25(21)$ \\
\hline$p$-value (Mann-Whitney U) & 0.947 & 0.002 & 0.004 \\
\hline Total & $10(9)$ & $13(12)$ & $28(20)$ \\
\hline
\end{tabular}

$I Q R=$ Interquartile range, $N S S M=$ Negative Sputum Smear Microscopy, $P X T B t=$ Positive Xpert TB test

attempt to rule out TB infection followed by positive Xpert TB test. The median time delay of 4 weeks or more in TB diagnosis and treatment, the WHO clinical 4th stage of HIV and patient not on HAART were associated with mortality. Additionally, primary healthcare facilities like Munhava, Chingussura and Manga Mascarenha, where the patients' flow is greater, including TB/HIV patients and, are distant from Ponta-Gea health facility where Xpert TB test are performed, were also associated with higher mortality.

Similar results have been reported that delays in TB diagnosis \& treatment and HAART initiation, advanced HIV infection and high risk associated with tuberculosis-immune reconstitution inflammatory syndrome are associated with high mortality among TB/HIV co-infected patients [30, 32-37].

Therefore, as Xpert assay is known to be faster and better sensitivity and specificity than sputum smear microscopy and, can effectively be used in resource-limited settings [23, 38-41] its use as a first tool of TB diagnosis should be promoted within the primary healthcare facilities in Beira to simplify patients' access to early and accurate diagnosis, thereby potentially decreasing severe TB cases and, associated TB mortality resulted from delays in TB diagnostic and treatment.

The main weakness of the study design is the use of retrospective data merely from TB/HIV co-infected patients with advanced HIV infection (WHO clinical 3rd 
Table 3 Risk factors associated with TB mortality among pulmonary TB/HIV co-infected patients in Beira city, Mozambique

\begin{tabular}{|c|c|c|c|c|}
\hline \multirow[t]{2}{*}{ Characteristics } & \multirow[t]{2}{*}{$\begin{array}{l}\text { Adjusted Odds } \\
\text { Ratio (aOR) }\end{array}$} & \multicolumn{2}{|c|}{$\begin{array}{l}\text { 95\% Confidence } \\
\text { Interval (Cl) }\end{array}$} & \multirow[t]{2}{*}{$P$-value } \\
\hline & & Minimum & Maximum & \\
\hline \multicolumn{5}{|c|}{ Time delays in days [Reference, $\leq 7$ days] } \\
\hline 8-14 days & 1.11 & 0.72 & 3.91 & 0.097 \\
\hline 15-21 days & 1.69 & 1.12 & 5.59 & 0.032 \\
\hline $22-28$ days & 4.02 & 2.31 & 9.92 & 0.001 \\
\hline$\geq 29+$ days & 12.40 & 5.70 & 22.10 & 0.001 \\
\hline \multicolumn{5}{|l|}{ Sex [Reference, female] } \\
\hline Male & 1.21 & 0.75 & 1.95 & 0.431 \\
\hline \multicolumn{5}{|c|}{ Age category [Reference, 15-24 years old] } \\
\hline $25-34$ years old & 1.09 & 0.44 & 2.68 & 0.850 \\
\hline 35-44 years old & 1.67 & 0.69 & 3.71 & 0.267 \\
\hline $45-54$ years old & 1.18 & 0.46 & 3.02 & 0.723 \\
\hline$>55$ years old & 1.23 & 0.43 & 3.54 & 0.705 \\
\hline \multicolumn{5}{|c|}{ WHO clinical stages of HIV [Reference, stage 3] } \\
\hline Stage 4 & 5.45 & 3.11 & 9.56 & 0.001 \\
\hline \multicolumn{5}{|c|}{ HAART [Reference, on HAART] } \\
\hline Not on HAART & 6.86 & 3.94 & 11.95 & 0.001 \\
\hline \multicolumn{5}{|c|}{ TB treatment center [Reference, Ponta-Gea] } \\
\hline Macurungo & 1.96 & 1.29 & 4.73 & 0.009 \\
\hline Manga Mascarenha & 2.08 & 1.51 & 5.18 & 0.001 \\
\hline Munhava & 3.13 & 1.93 & 6.37 & 0.001 \\
\hline Nhaconjo & 1.89 & 1.31 & 4.92 & 0.003 \\
\hline Chingussura & 2.71 & 1.74 & 5.03 & 0.006 \\
\hline
\end{tabular}

$a O R=$ adjusted Odds Ratio, HAART = Highly active antiretroviral therapy

and 4th stages of HIV) who are more likely to have negative sputum smear microscopy and high mortality. Additionally, the study design was not adequate to determine the time and causes of mortality among TB/HIV co-infected patients, which should provide further insight into some findings. However, a multicentre prospective cohort study [30] and a systematic review and meta-analysis [35] have documented that most deaths occurred within the first 3 months of HAART initiation before anti-TB drugs and within the first 2 weeks of anti-TB therapy.

\section{Conclusions}

Our study suggested that time delays in TB diagnosis and treatment resulting from initial negative sputum smear microscopy, but consecutive positive GeneXpert MTB/RIF test are common in Beira city and, is one of the main factors associated with mortality among TB/ HIV co-infected patients. Applying GeneXpert assay as gold standard for HIV-positive patients with suspected pulmonary TB or replacing the sputum smear microscopy by Xpert assay at all, and its availability within $24 \mathrm{~h}$ is urgently needed to ensure early diagnosis and treatment, and to maximize the impact of the few resources available in the country. This approach can also help in reducing the transmission of tuberculosis and the development of severe cases of $\mathrm{TB}$, as well as in reducing $\mathrm{TB}$ mortality related to the delay in diagnosis and treatment.

\section{Abbreviations}

aOR: Adjusted odds ratio; CIOB: Centro de investigação operacional da beira; FCG: Calouste gulbenkian foundation; EC: Estefano colove; HAART: Highly active antirretroviral therapy; HIV: Human immunodeficiency virus; IF: Inês fronteira; INS: Instituto Nacional de Saúde; IHMT: Instituto de Higiene e Medicina Tropical; IQR: Interquartile range; MROM: Maria do Rosário Oliveira Martins; MN: Marques Nhamonga; ML: Miguelhete Lisboa; NSSM: Negative Sputum Smear Microscopy; PXTBt: Positive Xpert TB test; TB: Tuberculosis; UNL: Universidade Nova de Lisboa; WHO: World Health Organization

\section{Acknowledgements}

The authors acknowledge the Tutorial Commission of the doctoral program of ML (Professors Sonia Dias and Miguel Viveiros); people who helped in the collection and processing of the database, namely Dércia de Jesus Rodrigues, Magaia Muarivai, Adérito Gustavo, and Argentino David; people who helped in translation and review of the manuscript, namely Pia Mueller, Germano Pires and Kingsley Ukwaja (my AuthorAid advisor), person who helped to design the map of health centres and TB services in Beira city, namely Yarin Abdula, the CIOB directorate and all colleagues, the Beira city health directorate and its all health centres, the IHMT - UNL; and the FCG for sponsoring the doctoral program of ML under award ID number P-135647/ SBG/2014

\section{Funding}

This study was elaborated based on the work of Miguelhete Lisboa doctoral program, a FCG scholarship holder and, used grants obtained from The Special Programme for Research and Training in Tropical Diseases (TDR) and co-sponsored by the United Nations Children's Fund (UNICEF), United Nations Development Programme (UNDP), World Bank and World Health Organization (WHO) - award ID number: B40151/2014.

The FCG and WHO/TDR were not involved in the design of the study and collection, analysis, and interpretation of data and in writing the manuscript, therefore, the authors are responsible for all information.

\section{Availability of data and materials}

The data that support the findings of this study are available from Mozambique Ministry of Health but restrictions apply to the availability of these data, which were used under license for the current study, and so are not publicly available. Data are however available from the authors upon reasonable request and with permission of the Mozambique Ministry of Health.

\section{Authors' contributions}

Conceived and designed the study $(\mathrm{ML})$ and reviewed methods and plan of data analysis of the study (IF and MROM). Data collection (ML, EC, MN), test performing and analysis (ML, EC, MN, IF and MROM). Data analysis and writing the manuscript (ML, EC, MN, IF, and MROM). All authors read, review and approved the final manuscript.

\section{Ethics approval and consent to participate}

The clinical data were collected as part of routine TB and HIV services, so informed consent was not required. The study protocol was approved by the institutional bioethics committee for health of the National Institute of Health of Mozambique, with registration ID number 039/CIBS-INS/2015.

\section{Competing interest}

The authors declare that they have no competing interest. 


\section{Authors' information}

$\mathrm{ML}$ is a MD, BSC, MSc working for CIOB/INS as an implementation \& operations research sciences Assistant and PhD candidate at IHMT-UNL. IF is an Auxiliary Professor of Epidemiology and co-advisor of ML at IHMT-UNL. EC is a BSC working for CIOB/INS as an implementation \& operations research sciences Assistant. MN is a BSC and MPH working for CIOB/INS as an implementation \& operations research sciences Assistant. MROM is a Full Professor of Biostatistics, Deputy Director of IHMT-UNL and principal advisor of ML.

\section{Consent for publication}

Not applicable.

\section{Publisher's Note}

Springer Nature remains neutral with regard to jurisdictional claims in published maps and institutional affiliations.

Received: 31 July 2017 Accepted: 26 December 2018

Published online: 07 January 2019

\section{References}

1. Golub JE, Bur S, Cronin WA, Gange S, Baruch N, Comstock GW, et al. Delayed tuberculosis diagnosis and tuberculosis transmission. Int J Tuberc Lung Dis Off J Int Union Tuberc Lung Dis. 2006;10(1):24-30.

2. Lin C-H, Tsai C-H, Liu C-E, Huang M-L, Chang S-C, Wen J-H, et al. 'Cough officer screening' improves detection of pulmonary tuberculosis in hospital in-patients. BMC Public Health. 2010;10:238.

3. Cheng $S$, Chen W, Yang Y, Chu P, Liu X, Zhao M, et al. Effect of diagnostic and treatment delay on the risk of tuberculosis transmission in Shenzhen, China: an observational cohort study, 1993-2010. PLoS One. 2013;8(6):e67516.

4. Greenaway C, Menzies D, Fanning A, Grewal R, Yuan L, FitzGerald JM, et al. Delay in diagnosis among hospitalized patients with active tuberculosis-predictors and outcomes. Am J Respir Crit Care Med. 2002;165(7):927-33.

5. Lawn SD, Myer L, Bekker L-G, Wood R. Burden of tuberculosis in an antiretroviral treatment programme in sub-Saharan Africa: impact on treatment outcomes and implications for tuberculosis control. AIDS Lond Engl. 2006;20(12):1605-12.

6. Lawn SD, Wood R. Tuberculosis in antiretroviral treatment Services in Resource-Limited Settings: addressing the challenges of screening and diagnosis. J Infect Dis. 2011;204(Suppl 4):S1159-67.

7. Karo B, Haas W, Kollan C, Gunsenheimer-Bartmeyer B, Hamouda O, Fiebig L. Tuberculosis among people living with HIV/AIDS in the German ClinSurv HIV cohort: long-term incidence and risk factors. BMC Infect Dis. 2014;14:148

8. WHO. Global tuberculosis report 2017 [Internet]. Geneva; 2017 [cited 2017 Nov 19]. Available from: http://apps.who.int/iris/bitstream/handle/10665/ 274453/9789241565646-eng.pdf?ua=1

9. Direcção Provincial de Saúde de Sofala (DPS-Sofala). Sofala Anual Tuberculosis Report. Beira, Mozambique: National Tuberculosis Control Programme - Ministéio de Saúde, Moçambique; 2016.

10. MISAU - Ministério da Saúde. Plano Estratégico do Sector da Saúde (PESS) 2014-2019 [Internet]. 2013 [cited 2017 Jun 19]. Available from: http://www. nationalplanningcycles.org/sites/default/files/planning_cycle_repository/ mozambique/pess_30_setembro_2013_detailh_com_anexos_vf_celia.pdf

11. MISAU - Ministério da Saúde. Relatório das Actividades de Tuberculose Desenvolvidas Durante o Ano 2014. Maputo, Moçambique: Ministério da Saúde - Programa Nacional de Controlo da Tuberculose; 2015.

12. Ward J, Siskind V, Konstantinos A. Patient and health care system delays in Queensland tuberculosis patients, 1985-1998. Int J Tuberc Lung Dis. 2001;5:1021-7.

13. Farah MG, Rygh JH, Steen TW, Selmer R, Heldal E, Bjune G. Patient and health care system delays in the start of tuberculosis treatment in Norway. BMC Infect Dis. 2006:6:33.

14. Sreeramareddy CT, Panduru KV, Menten J, Van den Ende J. Time delays in diagnosis of pulmonary tuberculosis: a systematic review of literature. BMC Infect Dis. 2009;9:91.

15. Maciel ELN, Golub JE, Peres RL, Hadad DJ, Fávero JL, Molino LP, et al. Delay in diagnosis of pulmonary tuberculosis at a primary health clinic in Vitoria, Brazil. Int J Tuberc Lung Dis Off J Int Union Tuberc Lung Dis. 2010;14(11):1403-10
16. Saifodine A, Gudo PS, Sidat M, Black J. Patient and health system delay among patients with pulmonary tuberculosis in Beira city, Mozambique. BMC Public Health. 2013;13:559.

17. WHO - World Health Organization. WHO | The End TB Strategy [Internet]. WHO. 2014 [cited 2017 Apr 18]. Available from: https://www.who.int/tb/ strategy/End_TB_Strategy.pdf

18. MISAU - Ministério da Saúde. Directrizes para a implementação do GENEXPERT ${ }^{\oplus}$ MTB/RIF em Moçambique. Ministério de Saúde - Moçambique; 2014.

19. Getahun H, Kittikraisak W, Heilig CM, Corbett EL, Ayles H, Cain KP, et al. Development of a standardized screening rule for tuberculosis in people living with HIV in resource-constrained settings: individual participant data meta-analysis of observational studies. PLoS Med. 2011;8(1):e1000391.

20. Dawson R, Masuka P, Edwards DJ, Bateman ED, Bekker L-G, Wood R, et al. Chest radiograph reading and recording system: evaluation for tuberculosis screening in patients with advanced HIV. Int J Tuberc Lung Dis Off J Int Union Tuberc Lung Dis. 2010;14(1):52-8.

21. Churchyard GJ, Fielding KL, Lewis JJ, Chihota VN, Hanifa Y, Grant AD. Symptom and chest radiographic screening for infectious tuberculosis prior to starting isoniazid preventive therapy: yield and proportion missed at screening. AIDS Lond Engl. 2010;24(Suppl 5):S19-27.

22. Cattamanchi A, Dowdy DW, Davis JL, Worodria W, Yoo S, Joloba M, et al. Sensitivity of direct versus concentrated sputum smear microscopy in HIV-infected patients suspected of having pulmonary tuberculosis. BMC Infect Dis. 2009;9:53.

23. Lawn SD, Brooks SV, Kranzer K, Nicol MP, Whitelaw A, Vogt M, et al. Screening for HIV-associated tuberculosis and rifampicin resistance before antiretroviral therapy using the Xpert MTB/RIF assay: a prospective study. PLoS Med. 2011;8(7):e1001067.

24. Cavanaugh JS, Shah NS, Cain KP, Winston CA. Survival among patients with HIV infection and smear-negative pulmonary tuberculosis - United States, 1993-2006. PLoS ONE [Internet] 2012;7(10). Available from: https://www. ncbi.n/m.nih.gov/pmc/articles/PMC3479118/pdf/pone.0047855.pdf

25. Zhang ZX, Sng L-H, Lin L, Cheng T, Seong N, Yong F. Delays in diagnosis and treatment of pulmonary tuberculosis in AFB smear-negative patients with pneumonia. Int J Tuberc Lung Dis. 2017;21(5):44-549.

26. MISAU. Tratamento Antiretroviral e Infecções Oportunistas do Adulto, Adolescente, Grávida e Criança. 2016;

27. MISAU. Manual de Diagnóstico e Tratamento de Tuberculose Resistente e Multi-Droga Resistente [Internet]. 2009. Available from: http://www.who.int/ hiv/pub/guidelines/mozambique_tb2.pdf

28. INE INDE. População Projectada por distritos, Sofala 2007_2040.xls — Instituto Nacional de Estatistica [Internet]. 2007 [cited 2017 Jan 27]. Available from: http://www.ine.gov.mz/estatisticas/estatisticas-demograficase-indicadores-sociais/populacao/projeccoes-da-populacao/projeccoes-20072040-sofala.pdf/view

29. Ministério do Trabalho, Emprego e Segurança Social. Lei 23/2007 de Lei de Trabalho [Internet]. Imprensa Nacional de Moçambique; 2007 [cited 2018 Jun 19]. Available from: http://www.mitess.gov.mz/sites/default/files/ documents/files/Lei\%2023\%202007\%20\%20Lei\%20de\%20Trabalho.pdf

30. MacPherson P, Dimairo M, Bandason T, Zezai A, Munyati SS, Butterworth AE, et al. Risk factors for mortality in smear-negative tuberculosis suspects: a cohort study in Harare, Zimbabwe. Int J Tuberc Lung Dis Off J Int Union Tuberc Lung Dis. 2011;15(10):1390-6.

31. Getahun $H$, Harrington $M, O$ 'Brien $R$, Nunn P. Diagnosis of smear-negative pulmonary tuberculosis in people with HIV infection or AIDS in resourceconstrained settings: informing urgent policy changes. Lancet. 2007; 369(9578):2042-9.

32. Gupta A, Nadkarni G, Yang W-T, Chandrasekhar A, Gupte N, Bisson GP, et al. Early mortality in adults initiating antiretroviral therapy (ART) in low- and middle-income countries (LMIC): a systematic review and meta-analysis. PLoS One 2011;6(12):e28691

33. van Lettow M, Åkesson A, Martiniuk ALC, Ramsay A, Chan AK, Anderson ST, et al. Six-month mortality among HIV-infected adults presenting for antiretroviral therapy with unexplained weight loss, chronic fever or chronic diarrhea in Malawi. PLoS ONE [Internet]. 2012;7(11). Available from: https:// www.ncbi.nlm.nih.gov/pmc/articles/PMC3501502/pdf/pone.0048856.pdf

34. Field N, Lim MS, Murray J, Dowdeswell RJ, Glynn JR, Sonnenberg P. Timing, rates, and causes of death in a large south African tuberculosis programme. BMC Infect Dis. 2014;14:3858. 
35. Abay SM, Deribe K, Reda AA, Biadgilign S, Datiko D, Assefa T, et al. The effect of early initiation of antiretroviral therapy in TB/HIV-Coinfected patients: a systematic review and meta-analysis. J Int Assoc Provid AIDS Care JIAPAC. 2015;14(6):560-70.

36. Bisson GP, Zetola N, Collman RG. Persistent high mortality in advanced HIV/TB despite appropriate antiretroviral and Antitubercular therapy: an emerging challenge. Curr HIV/AIDS Rep. 2015;12(1):107-16.

37. Nagu TJ, Aboud S, Mwiru R, Matee MI, Rao M, Fawzi WW, et al. Tuberculosis associated mortality in a prospective cohort in sub Saharan Africa: association with HIV and antiretroviral therapy. Int J Infect Dis. 2017:56:39-44

38. Boehme CC, Nicol MP, Nabeta P, Michael JS, Gotuzzo E, Tahirli R, et al. Feasibility, diagnostic accuracy, and effectiveness of decentralised use of the Xpert MTB/RIF test for diagnosis of tuberculosis and multidrug resistance: a multicentre implementation study. Lancet. 2011:377(9776):1495.

39. Lin S-YG, Desmond EP. Molecular diagnosis of tuberculosis and drug resistance. Clin Lab Med. 2014:34(2):297-314.

40. Steingart KR, Schiller I, Horne DJ, Pai M, Boehme CC, Dendukuri N. Xpert ${ }^{\oplus}$ Mtb/Rif assay for pulmonary tuberculosis and rifampicin resistance in adults. Cochrane Database Syst Rev. 2014;1:1-166.

41. Cox H, Dickson-Hall L, Ndjeka N, Van't Hoog A, Grant A, Cobelens F, et al. Delays and loss to follow-up before treatment of drug-resistant tuberculosis following implementation of Xpert MTB/RIF in South Africa: a retrospective cohort study. PLoS Med [Internet]. 2017;14(2). Available from: https://www. ncbi.nlm.nih.gov/pmc/articles/PMC5319645/pdf/pmed.1002238.pdf.

Ready to submit your research? Choose BMC and benefit from:

- fast, convenient online submission

- thorough peer review by experienced researchers in your field

- rapid publication on acceptance

- support for research data, including large and complex data types

- gold Open Access which fosters wider collaboration and increased citations

- maximum visibility for your research: over $100 \mathrm{M}$ website views per year

At $\mathrm{BMC}$, research is always in progress.

Learn more biomedcentral.com/submissions 